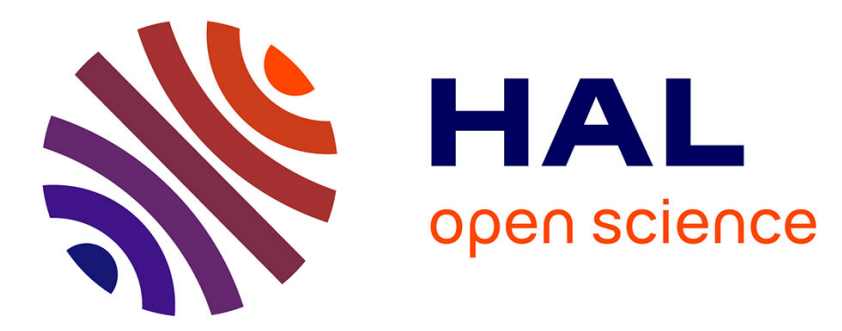

\title{
Sex and Age Differences in the Endorsement of Sex Stereotypes Associated with Driving
}

Karyn Pravossoudovitch, Cécile Martha, François Cury, Marie-Axelle Granié

\section{To cite this version:}

Karyn Pravossoudovitch, Cécile Martha, François Cury, Marie-Axelle Granié. Sex and Age Differences in the Endorsement of Sex Stereotypes Associated with Driving. Spanish Journal of Psychology, 2015, 18, pp.E100. 10.1017/sjp.2015.94 . hal-01260164

\section{HAL Id: hal-01260164 \\ https://hal.science/hal-01260164}

Submitted on 21 Jan 2016

HAL is a multi-disciplinary open access archive for the deposit and dissemination of scientific research documents, whether they are published or not. The documents may come from teaching and research institutions in France or abroad, or from public or private research centers.
L'archive ouverte pluridisciplinaire HAL, est destinée au dépôt et à la diffusion de documents scientifiques de niveau recherche, publiés ou non, émanant des établissements d'enseignement et de recherche français ou étrangers, des laboratoires publics ou privés. 
Pour citer cette référence : Pravossoudovitch, K., Martha, C., Cury, F., \& Granié, M.-A. (2015). Sex and age differences in the endorsement of sex stereotypes associated with driving. Spanish Journal of Psychology, 18, E100. doi: 10.1017/sjp.2015.94

Sex and Age Differences in the Endorsement of Sex Stereotypes Associated with Driving Karyn Pravossoudovitch ${ }^{2}$, Cécile Martha ${ }^{1}$, François Cury ${ }^{1}$ and Marie-Axelle Granié ${ }^{2}$

${ }^{1}$ Aix-Marseille Université (France)

${ }^{2}$ IFSTTAR-LMA (France)

Correspondence concerning this article should be addressed to Karyn Pravossoudovitch. 304. chemin de la croix blanche. F-13300. Salon de Provence (France). Phone: +33-0490568621. E-mail: karyn.pravossoudovitch@ifsttar.fr 


\begin{abstract}
Sex and age differences are particularly pronounced in car accidents. Current psychological research is exploring the relationship between risky driving and compliance with sex stereotypes, notably conformity with social expectations concerning masculinity. Some studies have already shown that sex stereotypes associated with driving (SSAD) may influence driving behaviors. The aim of this research was to explore the participants' sex and age differences in SSAD endorsement. A questionnaire was developed and validated on four dimensions of SSAD: male's driving skills and female's compliance with traffic rules, courtesy behind the wheel, and risk avoidance in driving. SSAD endorsement was measured for 291 licensed drivers from 18 to 64 years of age. Results revealed that females endorsed the female's risk avoidance stereotype more $(\mathrm{p}<.05)$, whereas males endorsed the male drivers (driving skills) stereotype more $(\mathrm{p}<.05)$. Results also revealed that the endorsement of male's driving skills decreases with age $(\mathrm{p}<.01)$ and the endorsement of female's courtesy increases with age among all participants $(\mathrm{p}=.01)$, while the endorsement of female's compliance with traffic rules increases with age only among female participants $(\mathrm{p}<.05)$. The results are discussed in terms of in-group/out-group relations and sex and age differences.
\end{abstract}

Received 12 December 2014; Revised 29 June 2015; Accepted 03 August 2015.

Keywords: stereotypes, sex, age, driving 
Worldwide, males are involved in about three times more car crashes than females (World Health Organization, 2002). Studies show that male drivers reported more traffic offenses and are involved in accidents related to these traffic offenses more than females (Simon \& Corbett, 1996). Differences in traffic exposure between males and females are not enough to explain the differences between the sexes in accidentology. Risk-taking and traffic offenses better explain sex differences in traffic fatalities than the number of kilometers travelled (Waylen \& McKenna, 2002).

Many psychologists indeed ascribe the male-female difference in risk-taking to sex stereotypes (Byrnes, Miller, \& Schafer, 1999). Sex stereotypes refer to characteristics and traits which are associated with males and females within a given culture (Unger, 1979). In France, as in other Western countries, masculinity is stereotypically associated with risk taking (Bem, 1981; Gana, 1995), and studies show that people conforming to masculine traits seem to have more risky practices than people conforming to feminine traits (Mahalik et al., 2003). Indeed, research shows that masculine stereotype conformity has a greater effect than feminine stereotype conformity on self-reported risky behaviors in driving behaviors (Özkan \& Lajunen, 2006), and in pedestrian behaviors (Granié, 2009). Sex stereotypes seem to be more predictive of risky behavior than biological sex (Granié, 2009). Indeed, a high level of masculinity is associated with a high level of offenses, aggressive violations and ordinary violations (Özkan \& Lajunen, 2006), with a higher number of accidents and greater perceptual motor skills. A high level of femininity is associated with high safety skills, few accidents and offenses, lower aggressive violations and ordinary violations (Özkan \& Lajunen, 2006). The association between masculinity and perceptual motor skills seem to suggest that "being a skillful driver" is seen as a masculine trait.

Since the dawn of the automobile era, driving has been perceived as a dirty, physical task, calling for masculine gender roles. In the same time females were stereotypically viewed 
as unable to manage stress when a quick decision is needed, as in driving activity (Berger, 1986).

Some studies carried out in France show that adults and adolescents define female drivers as careful, compliant with traffic rules and having less severe traffic accidents than male drivers, although they are seen as unskilled drivers, having a lot of fender-bender accidents, and involved in an activity inconsistent with their social roles (Félonneau \& Becker, 2011; Granié \& Papafava, 2011). In contrast, French adolescents define male drivers as skillful and involved in an activity consistent with their social roles, although careless and committing more offenses (Granié \& Papafava, 2011). Degraeve, Granié, and Pravossoudovitch (2014) then confirmed these results on French adults from 16 to 85 years old. They showed that people perceive male drivers as skillful although impatient, reckless, uncivil, committing offenses and driving too fast, while they see female drivers as civic, careful, vigilant, and complying with traffic rules, although unskilled, dangerous, inattentive, and driving slowly. Four major dimensions differentiating male and female drivers arise from this study: driving skills, courtesy behind the wheel, compliance with traffic rules and risk avoidance in driving (Degraeve et al., 2014).

These differentiated beliefs about the driving abilities of male and female have implications on male and female's behaviors and may cause a stereotype threat effect on female drivers (Chateignier, Chekroun, Nugier, \& Dutrévis, 2011; Félonneau \& Becker, 2011; Yeung \& von Hippel, 2008). Nevertheless, nothing is known about sex differences in the endorsement of the sex stereotypes associated with driving (SSAD).

The objective of the present study is therefore to explore the differences in endorsement of SSAD according to the driver's sex and age. The hypothesis is that SSAD endorsement varies according to the participant's sex and age in different ways depending on domains of the SSAD. Indeed Degraeve et al. (2014) showed that individuals promote their 
own sex group while they denigrate the out-group through the characteristics they associate with drivers of each sex group. Women, more than men, perceive male drivers as careless and female drivers as careful, while men, more than women, perceive female drivers as unskilled and male drivers as skilled. Furthermore, Granié and Papafava (2011) showed that the male driver's stereotype is stable from age eleven on, while the female driver's stereotype appears to grow stronger with age.

\section{Method}

\section{Materials}

\section{Measuring SSAD endorsement}

To the best of our knowledge, no tool currently exists to measure SSAD endorsement. In order to explore sex and age differences, a questionnaire has been developed to measure the individual's degree of endorsement of these stereotypes.

This questionnaire focuses on the four dimensions differentiating male and female drivers (Berger, 1986; Chateignier et al., 2011; Degraeve et al., 2014; Félonneau \& Becker, 2011; Granié \& Papafava, 2011): driving skills, courtesy behind the wheel, compliance with traffic rules and risk avoidance in driving (Degraeve et al., 2014). The questionnaire was divided into two sections (male/female drivers). Based on the adjectives participants gave in the free association questionnaire used to describe male and female drivers in the study from Degraeve et al. (2014), 33 items in total were developed. These items were duplicated for male and female drivers and described characteristics of male/female drivers.

Several pre-tests were undertaken to improve comprehension of items among the targeted population. The purpose of these pre-tests was to determine whether the items that make up the experimental version of the questionnaire were clear, unambiguous and expressed in a language that is understood by the target population. Each section (male and 
female drivers) of the SSAD questionnaire was finally made up of 27 items on four dimensions of SSAD: 7 items concerning driving skills (e.g., "I think that males/females are skillful behind the wheel"), 7 items concerning compliance with traffic rules (e.g., "I think that males/females comply with speed limits"), 7 items concerning risk avoidance in driving (e.g., "I think that males/females avoid to adopt a risky driving") and 6 items concerning courtesy behind the wheel (e.g., "I think that males/females are courteous drivers"). In each section, items were alternated among all the dimensions (compliance with traffic rules, driving skills, risk avoidance and courtesy). The order of the items was the same for both sections. As in the study from Chateignier et al. (2011), evaluations of male and female drivers were measured through the participants' agreement with different statements on a seven-point scale ( 1 = "not agree at all", to 7 = "strongly agree").

\section{Evaluations of male and female drivers}

For each dimension, a score was calculated for male drivers and for female drivers by summing the scores of each item of the dimension. Finally 8 scores were obtained (4 scores concerning male drivers and 4 scores concerning female drivers). Scores ranged from 0 to 49 for the dimensions concerning driving skills, compliance with traffic rules, and risk avoidance (7 items in each dimension) and from 0 to 42 for the dimension concerning courtesy behind the wheel (6 items). The more the participants had a high score, the more they had a positive image of male or of female drivers on the corresponding dimension (males/females are skillful drivers, males/females are compliant with traffic rules, males/females avoid risk taking in driving, males/females are courteous drivers).

\section{Stereotype endorsement}

An index of stereotype endorsement was then calculated for each of the 4 dimensions of SSAD. As already used in a previous study on sex stereotypes in mathematics (Bonnot \& 
Croizet, 2007), the index of stereotype endorsement was calculated for each of the 4 dimensions of SSAD, using the difference between participants' evaluations of male and of female drivers. The endorsement index for each domain of SSAD corresponded to the rating of the sex group targeted by the stereotype after controlling for the rating of the other sex group $^{1}$

These evaluation indexes ranged from -49 to 49 for the dimensions concerning driving skills, compliance with traffic rules, and risk avoidance and from -42 to 42 for the dimension concerning courtesy behind the wheel. A score close to 0 meant that participant did not endorse the SSAD and evaluated male and female drivers similarly. The more the score was positive, the more the participant endorsed the stereotype (male driver as skilled, female drivers as courteous, risk avoider and compliant), the more the score was negative, the more the participant expressed a counterstereotyped belief (female drivers as skilled, male drivers as courteous, risk avoider and compliant).

\section{Participants and procedure}

In order to obtain the widest sample possible, we undertook a web-based collection using social networks. Only results from participants living in France were kept. The participants answered the questionnaire individually after giving their informed consent. The responses were anonymous, as the individuals were only identified by the day and time of completion of the questionnaire. The questionnaire was completed online by 291 licensed drivers (119 men and 172 women), from 18 to 64 years old. Their mean age was 36.36 years old $(S D=14.41)$. This questionnaire was presented to participants as a simple questionnaire concerning driving. The section on male drivers and the section on female drivers in the

\footnotetext{
${ }^{1}$ Male's driving skills index = participants' ratings for male's minus female's driving skills Female's courtesy index = participants' ratings for female's minus male's courtesy behind the wheel Female's compliance index = participants' ratings for female's minus male's compliance with traffic rules Female's risk avoidance index = participants' ratings for female's minus male's risk avoidance
} 
SSAD questionnaire were proposed in a counterbalanced order (i.e., 136 participants began with the section on male drivers and 155 began with the section on female drivers). In order to remain consistent with the age groups defined by the French Interministerial Observatory for Road Safety (French Interministerial Observatory for Road Safety, 2012) in the French traffic accident statistics, the participants were divided into three age groups: 18 to 24 years old $(N=$ 94, 35 men and 59 women; $\left.\mathrm{M}_{\mathrm{age}}=21.95, S D=1.59\right), 25$ to 44 years old $(N=107,44$ men and 63 women; $\left.\mathrm{M}_{\mathrm{age}}=33.10, S D=5.80\right)$ and 45 to 64 years old $(N=90,40$ men and 50 women; $\left.\mathrm{M}_{\mathrm{age}}=55.30, S D=6.28\right)$.

\section{Data analysis}

Firstly, using Lisrel 8.8, confirmatory factor analysis (CFA) was conducted on each section of the SSAD questionnaire to insure the good factor structure of the questionnaire. Solutions were generated using maximum likelihood estimations. A model was considered as adequate if the comparative fit index (CFI) and the non-normed fit index (NNFI) were greater than or equal to .95 , and if the rootmean square residual (RMSEA) and the standardized root mean square residual (SRMR) were lower or equal to .08 (Hu \& Bentler, 1999). Skewness and Kurtosis Z-values were generated using SPSS 20.0 for each item of the questionnaire and the distribution was considered as normal if z-value was within -1.96 and +1.96 (Cramer \& Howitt, 2004).

Secondly, ANOVA and LSD post hoc were used to explore the effects of participants' sex, participants' age, and their interaction on participants' evaluations of male and female drivers for each domain of SSAD.

Thirdly, ANOVA and LSD post hoc were used to explore the effects of participants' sex, participants' age, and their interaction on participants' endorsement indexes for each domain of the SSAD. 


\section{Results}

\section{Analysis of the questionnaire structure}

The results of the CFA conducted on the male-drivers section are presented in table 1. They support the hypothesized four-factor structure and all the standardized factor analysis loadings ranged from .60 to .93 . Each fit statistic met the criteria for a good fitting model (Hu $\&$ Bentler, 1999): $\mathrm{chi}^{2} / \mathrm{df}=2.08, p<.001, \mathrm{CFI}=.99, \mathrm{NNFI}=.98$, SRMR $=.04$, RMSEA $=$ $.06, \mathrm{ECVI}=2.69, \mathrm{IFI}=.99$.

The results of the CFA conducted on the female-drivers section are presented in table 2. They support the hypothesized four-factor structure and all the standardized factor loadings ranged from .50 to .95 . Each fit statistic met the criteria for a good fitting model $(\mathrm{Hu} \&$ Bentler, 1999): $\mathrm{chi}^{2} / \mathrm{df}=2.76, p<.001, \mathrm{CFI}=.97, \mathrm{NNFI}=.97, \mathrm{SRMR}=.06, \mathrm{RMSEA}=.08$, $\mathrm{ECVI}=3.43, \mathrm{IFI}=.97$

[Please insert table 1 here]

Results of the CFA supported the four-factor structure in each section of the questionnaire, so four endorsement indexes were computed: male's driving skills (Cronbach's $\alpha=.93$ ), female's courtesy behind the wheel (Cronbach's $\alpha=.95$ ), female's compliance with traffic rules (Cronbach's $\alpha=.88$ ) and female's risk avoidance in driving (Cronbach's $\alpha=$ $.94)$.

\section{Evaluations of male drivers according to sex and age}

ANOVA were carried out on the effects of participants' sex (2) and age (3) for all the evaluations concerning male drivers: driving skills, courtesy behind the wheel, compliance 
with traffic rules and risk avoidance in driving. The means and standard deviations for each male driver's evaluation for each participant's age and sex group are presented in table 3 .

ANOVA on the evaluation of male driver's skills and male driver's courtesy behind the wheel revealed no main effect of participants' sex, participants' age and participants' age $\mathrm{x}$ sex interaction.

ANOVA on the evaluation of male drivers' compliance with traffic rules revealed no main effect of participants' age and participants' sex, but a significant participants' age x sex interaction $\left(F(2,285)=4.50, p=.01, \eta_{p}{ }^{2}=.03\right)$. LSD post hoc analysis $(p<.05)$ indicated that the men aged 45 to 64 evaluated male drivers as more compliant with traffic rules than the same-age women and the younger age-groups of both sexes did.

ANOVA on the evaluation of male driver's risk avoidance revealed a significant main effect of participants' age $\left(F(2,285)=3.15, p<.05, \eta_{p}^{2}=.02\right)$, but no participants' sex or participants' age $\mathrm{x}$ sex interaction. Post hoc analysis indicated that the 45-64 age-group evaluated male drivers as more risk avoiders than the 18-24 age-group did.

\section{Evaluations of female drivers according to sex and age}

ANOVAs were carried out on the effects of participants' sex (2) and age (3) for all the evaluations concerning female drivers: driving skills, courtesy behind the wheel, compliance with traffic rules and risk avoidance in driving. The means and standard deviations for each female driver's evaluation for each participant's age and sex group are presented in table 3 .

ANOVA on the evaluation of female driver's skills revealed a significant main effect of participants' sex $\left(F(1,285)=17.76, p<.001, \eta_{p}{ }^{2}=.06\right)$, participants' age $(F(2,285)=$ 7.74, $\left.p=.001, \eta_{p}{ }^{2}=.05\right)$, but no participants' age $\mathrm{x}$ sex interaction. Post hoc analysis indicated that the women and the 45-64 age-group evaluated female drivers as more skillful than the men and the younger age-groups did. 
ANOVA on the evaluation of female driver's courtesy behind the wheel revealed a significant main effect of participants' age $\left(F(2,285)=5.11, p<.01, \eta_{p}{ }^{2}=.04\right)$, but no participants' sex or participants' age x sex interaction. Post hoc analysis indicated that the 4564 age-group evaluated female drivers as more courteous behind the wheel than the younger age-groups did.

ANOVA on the evaluation of female's compliance with traffic rules revealed a significant main effect of participants' age $\left(F(2,285)=4.97, p<.01, \eta_{p}{ }^{2}=.03\right)$, but no participants' sex or participants' age x sex interaction. Post hoc analysis indicated that the 1824 age-group evaluated female drivers as less compliant with traffic rules than the older agegroups did.

ANOVA on the evaluation of female drivers' risk avoidance revealed a significant main effect of participants' $\operatorname{sex}\left(F(1,285)=4.14, p<.05, \eta_{p}^{2}=.01\right)$, participants' age $(F(2$, $\left.285)=3.10, p<.05, \eta_{p}{ }^{2}=.02\right)$, but no participants' age $\mathrm{x}$ sex interaction. Post hoc analysis indicated that the women and the 45-64 age-group evaluated female drivers as more risk avoiders than men and the 18-24 age-group did.

[Please insert table 2 here]

\section{Endorsement of SSAD according to sex and age}

ANOVA were carried out on the effects of participants' sex (2) and age (3) on all the indexes measuring endorsement of SSAD: male's driving skills, female's courtesy behind the wheel, female's compliance with traffic rules and female's risk avoidance in driving. The means and standard deviations for each endorsement index for each participant's age and sex group are presented in figure 1. 
ANOVA on the stereotype endorsement index concerning male's driving skills revealed a significant main effect of participants' $\operatorname{sex}\left(F(1,285)=5.32, p<.05, \eta_{p}{ }^{2}=.02\right)$, participants' age $\left(F(2,285)=6.95, p=.001, \eta_{p}{ }^{2}=.05\right)$, but no participants' age $\mathrm{x}$ sex interaction. Post hoc analysis indicated that the men and the 45-64 age-group endorsed the stereotype on male's driving skills more than the women and the younger age-groups did.

ANOVA on the stereotype endorsement index concerning female's courtesy behind the wheel revealed a significant main effect of participants' age $(F(2,285)=4.36, p=.001$, $\left.\eta_{p}{ }^{2}=.03\right)$, but no participants' sex or participants' age $\mathrm{x}$ sex interaction. Post hoc analysis indicated that the 45-64 age-group endorsed the stereotype on female driver's courtesy more than the 18-24 age-group did.

ANOVA on the stereotype endorsement index concerning female's compliance with traffic rules revealed no main effect of participants' age and participants' sex, but a significant participants' age x sex interaction $\left(F(2,285)=3.49, p<.05, \eta_{p}{ }^{2}=.02\right)$. Post hoc analysis indicated that the women aged 45 to 64 endorsed the stereotype on female driver's compliance more than the men of the same age and the 18-24 year-old women did.

ANOVA on the stereotype endorsement index concerning female's risk avoidance revealed a significant main effect of participants' $\operatorname{sex}\left(F(1,285)=4.59, p<.05, \eta_{p}{ }^{2}=.02\right)$, but no participants' age and participants' age x sex interaction. Indeed, the women endorsed the stereotype on female driver's risk avoidance more than the men did.

[Please insert figure 1 here]

\section{Discussion}


The aim of the present study is to explore the effects of participants' sex and participants' age on the endorsement of female and male driver's stereotypes among French adults.

A questionnaire measuring SSAD was therefore created. Results indicate that each section of the questionnaire (i.e., male and female drivers) is organized in the hypothesized four-factor structure: risk avoidance, driving skills, compliance with traffic rules, and courtesy behind the wheel. These results are in line with previous studies which have shown that these four dimensions differentiate stereotypes on male and female drivers (Berger, 1986; Chateignier et al., 2011; Degraeve et al., 2014; Félonneau \& Becker, 2011; Granié \& Papafava, 2011).

Concerning sex differences in the endorsement of SSAD, results show no sex differences in the endorsement of the stereotypes stating that females are more compliant with traffic rules and more courteous behind the wheel than males. Thus, both sex groups seem to agree on those aspects of female driver's behavior: compliance with traffic rules and courtesy behind the wheel are perceived as higher among female drivers. However sex differences are found in the endorsement of the stereotype stating that female drivers are more risk avoiders than males and that male drivers are more skillful drivers than females. In both cases, this result is due to a sex difference in the score attributed to female drivers. Indeed women evaluate female's risk avoidance higher than men do, while men evaluate female's driving skills lower than women do. Thus, men denigrate female drivers for the stereotype concerning male drivers whereas women enhance female drivers for a stereotype concerning female drivers. These results are in keeping with research on sex stereotypes, and more generally on intergroup relations, which have shown how individuals seek positive distinctiveness by denigrating the out-group while promoting the in-group (Tajfel \& Turner, 1986). Power-based gender stereotype approaches (Zemore \& Fiske, 2000) and the effects of social asymmetry 
between the sexes (Hurtig, Kail, \& Rouch, 2002) can provide an additional understanding of these results. Thus, research has shown that the dominant position of the male group (LorenziCioldi, 1988) leads members of the socially dominated female group to over-promote the ingroup (Rudman \& Goodwin, 2004) and to defend their gender group identity more than males feel the need to.

Concerning age differences in the endorsement of SSAD, age differences are found in the stereotype concerning male's driving skills and female's courtesy behind the wheel. In both cases, this result is due to an increase with age in the score attributed to female drivers. More broadly, the increase with age in the score attributed to female drivers is observable for all the scores concerning female drivers. Conversely, only one score concerning male drivers change with age, with older participants perceiving male drivers as more risk avoiders than the younger participants do. These results are in keeping with previous research on sex stereotypes associated with driving, which have shown that the social representation of male drivers remains steady from the age of eleven, whereas the social representation of female drivers varies with age (Degraeve et. al, 2014; Granié \& Papafava, 2011). Driving is, from an early age, associated with male's roles. Thus, male driver is the normative reference for drivers (Dontsov \& Kabalevskaya, 2013), base on which, by differentiation and opposition, the typical behavior of female drivers is defined, being more ambivalent and heterogeneous due to the different identity issues for males and females.

In the present study, a questionnaire measuring four dimensions of SSAD is created. Although this questionnaire show good internal reliability and is able to measure the endorsement of stereotypes concerning male and female drivers without the participants' having to compare them directly, some precautions must be taken in the use of the results. Indeed, we undertake a web-based survey, but only $63 \%$ of households have internet access at home in France (Deroin, 2010), mainly among the middle and upper socioprofessional 
categories, whereas socioeconomic status could influence perception of male and female drivers (Degraeve, Granié, Lo Monaco, \& Pravossoudovitch, 2015). Future research should confirm these results on a larger and more representative sample of the French population. Moreover, this questionnaire is not age specific. Indeed, when participants rate male and female drivers, the age that participants attribute to the driver is not taken into account and therefore not controlled. Future research should take this parameter into consideration, as it could potentially influence the participant's endorsement of the different stereotypes for male and female drivers. Finally this SSAD questionnaire is made up of 54 items (27 items in each section) and may be too long for use with other self-reporting measures and lead to overly lengthy completion time. Future studies could create a shorter version that is capable of measuring SSAD with fewer items and use such a tool to measure driving-related stereotypes in the French population in order to study the influence of the endorsement of these stereotypes on other self-reporting measures such as driving self-efficacy and driving behaviors.

\section{References}

Bem, S. L. (1981). Gender schema theory: A cognitive account of sex typing. Psychological Review, 88, 354-364. http://dx.doi.org/10.1037/0033-295x.88.4.354

Berger, M. L. (1986). Women drivers!: The emergence of folklore and stereotypic opinions concerning feminine automotive behavior. Women's Studies International Forum, 9, 257-263. http://dx.doi.org/10.1016/0277-5395(86)90061-0

Bonnot, V., \& Croizet, J.-C. (2007). Stereotype internalization and women's math performance: The role of interference in working memory. Journal of Experimental Social Psychology, 43, 857-866. 
Byrnes, J. P., Miller, D. C., \& Schafer, W. D. (1999). Gender differences in risk taking: A meta-analysis. Psychological Bulletin, 125, 367-383. http://dx.doi.org/10.1037/00332909.125.3.367

Chateignier, C., Chekroun, P., Nugier, A., \& Dutrévis, M. (2011). «Femme au volant...»: Effet de la menace du stéréotype et de la colère sur les performances des femmes à une tâche liée à la conduite automobile [«Death awaiting women drivers»: Effect of stereotype threat and anger on women performance to a driving rules task]. Année Psychologique, 111, 673-700.

Cramer, D., \& Howitt, D. (2004). The sage dictionary of statistics : a practical resource for students in the social sciences. Thousand Oaks : Sage.

Degraeve, B., Granié, M.-A., \& Pravossoudovitch, K. (2014, Avril). Gender stereotypes and social representations associated with vehicle among French adults. Women's Issues In Transportation "Bridging the Gap", Proceedings of the 5th International Conference on Women's Issues In Transportation. (pp. 141-150). Paris, France: Fédération Internationale de l'automobile.

Degraeve, B., Granié, M.-A., Lo Monaco, G., \& Pravossoudovitch, K. (2015). Social representations associated with men and women drivers among French adolescents and adults. Effects of perceiver's age, sex, and socioeconomic status. Transportation Research Part F: Traffic Psychology and Behaviour, 34, 1-17. http://dx.doi.org/ 10.1016/j.trf.2015.07.019.

Deroin, V. (2010). Diffusion et utilisation des tic en France et en Europe en 2009 [Spread and use of ICT in France and Europe in 2009]. Culture chiffres, 2, 1-12. http://dx.doi.org/10.3917/culc.102.0001

Dontsov, A. I., \& Kabalevskaya, A. I. (2013). Gender stereotypes among road users. Psychology in Russia: State of the Art, 6, 150-163. 
Félonneau, M.-L., \& Becker, M. (2011). «Femmes au volant, danger au tournant» Les conductrices sont-elles victimes d'une menace de stéréotype? [Women at the wheel, danger round the bend. Are female drivers victim of a stereotype threat?]. Psychologie du Travail et des Organisations, 17, 314-329.

French Interministerial Observatory for Road Safety. (2012). Assessment of French road safety. Paris, France, Author. Retrieved from: http://www.securite-routiere.gouv.fr/

Gana, K. (1995). Androgynie psychologique et valeurs socio-cognitives des dimensions du concept de soi [Psychological androgyny and sociocognitive dimensions of the self concept]. Cahiers Internationaux de Psychologie Sociale, 25, 27-43.

Granié, M.-A. (2009). Effects of gender, sex-stereotype conformity, age and internalization on risk-taking among adolescent pedestrians. Safety Science, 47, 1277-1283. http://dx.doi.org/10.1016/j.ssci.2009.03.010

Granié, M.-A., \& Papafava, E. (2011). Gender stereotypes associated with vehicle driving among French preadolescents and adolescents. Transportation Research Part F: Traffic Psychology and Behaviour, 14, 341-353. http://dx.doi.org/10.1016/j.trf.2011.04.002

Hu, L., \& Bentler, P. M. (1999). Cutoff criteria for fit indexes in covariance structure analysis: Conventional criteria versus new alternatives. Structural Equation Modeling, $6,1-55$.

Hurtig, M.-C., Kail, M., \& Rouch, H. (2002). Sexe et genre: De la hiérarchie entre les sexes [Sex and gender: Hierarchy between sex]. Paris, France: Centre national de la recherche scientifique Editions.

Lorenzi-Cioldi, F. (1988). Individus dominants et groupes dominés [Dominant individuals and dominated groups] Grenoble, France : Presses Universitaires de Grenoble.

Mahalik, J. R., Locke, B. D., Ludlow, L. H., Diemer, M. A., Scott, R. P. J., Gottfried, M., \& Freitas, G. (2003). Development of the conformity to masculine norms inventory. Psychology of Men \& Masculinity, 4(1), 3-25. http://dx.doi.org/10.1037/1524-9220.4.1.3 
Özkan, T., \& Lajunen, T. (2006). What causes the differences in driving between young men and women? The effects of gender roles and sex on young drivers' driving behaviour and self-assessment of skills. Transportation Research Part F: Traffic Psychology and Behaviour, 9, 269-277.

Rudman, L. A., \& Goodwin, S. A. (2004). Gender differences in automatic in-group bias: Why do women like women more than men like men? Journal of Personality and Social Psychology, 87, 494-509. http://dx.doi.org/10.1037/0022-3514.87.4.494

Simon, F., \& Corbett, C. (1996). Road traffic offending, stress, age, and accident history among male and female drivers. Ergonomics, 39, 757-780. http://dx.doi.org/10.1080/00140139608964497

Tajfel, H., \& Turner, J. C. (1986). The social identity theory in intergroup behavior. In S. Worchel \& W. Austin (Eds.), Psychology of intergroup relations ( $2^{\text {nd }}$ Ed., pp. 7-24). Chicago, IL : Nelson-Hall.

Unger, R. K. (1979). Toward a redefinition of sex and gender. American Psychologist, 34, 1085-1094. http://dx.doi.org/10.1037/0003-066x.34.11.1085

Waylen, A., \& Mckenna, F. (2002). Cradle attitudes - graves consequences. The development of gender differences in risky attitudes and behaviour in road use. Reading, UK: The University of Reading. Foundation for Road Safety Research.

World Health Organization. (2002). Gender and road traffic injuries. Geneva, Switzerland: Department of Gender and Women's Health.

Yeung, N. C. J., \& von Hippel, C. (2008). Stereotype threat increases the likelihood that female drivers in a simulator run over jay-walkers. Accident Analysis and Prevention, 40, 667-674.

Zemore, S. E., \& Fiske, S. T. (2000). Gender stereotypes and the dynamics of social interaction. In T. Eckes \& H. M. Trautner (Eds.), The Developmental Social 
Psychology of Gender (pp. 207-241). London, England: Lawrence Erlbaum Associates. 


\section{Table 1.}

Confirmatory factor analysis of the male (and the female) drivers section

\begin{tabular}{|c|c|c|c|c|}
\hline Items & $\begin{array}{l}\text { Compliance with } \\
\text { traffic rules }\end{array}$ & $\begin{array}{c}\text { Driving } \\
\text { skills }\end{array}$ & $\begin{array}{c}\text { Risk } \\
\text { avoidance }\end{array}$ & Courtesy \\
\hline 17I think that males (females) don't exceed speed limits & $.93(.88)$ & & & \\
\hline 25I think that males (females) respect speed limits & $.90(.87)$ & & & \\
\hline 9 I think that males (females) don't break speed limits & $.89(.86)$ & & & \\
\hline $\begin{array}{l}21 \text { I think that males (females) don't exceed the permitted } \\
\text { alcohol limit for driving }\end{array}$ & $.82(.64)$ & & & \\
\hline 1 I think that males (females) comply with speed limits & .74 (.72) & & & \\
\hline $\begin{array}{l}5 \text { I think that males (females) respect the permitted alcohol } \\
\text { limit for driving }\end{array}$ & $.66(.53)$ & & & \\
\hline 13I think that males (females) never run red lights & $.60(.50)$ & & & \\
\hline 18I think that males (females) are skillful behind the wheel & & $.89(.93)$ & & \\
\hline 14I think that males (females) have good driving abilities & & $.89(.87)$ & & \\
\hline 22I think that males (females) have a good driving dexterity & & $.87(.87)$ & & \\
\hline $\begin{array}{l}\text { 26I think that males (females) know how to maneuver their } \\
\text { vehicle }\end{array}$ & & $.84(.86)$ & & \\
\hline 6 I think that males (females) are dexterous behind the wheel & & $.84(.89)$ & & \\
\hline 10I think that males (females) have good driving skills & & $.83(.88)$ & & \\
\hline $\begin{array}{l}2 \text { I think that males (females) have a good mastery of their } \\
\text { vehicle }\end{array}$ & & $.76(.82)$ & & \\
\hline $\begin{array}{l}\text { 19I think that males (females) refrain from having risky } \\
\text { behaviors behind the wheel }\end{array}$ & & & $.92(.93)$ & \\
\hline $\begin{array}{l}\text { 23I think that males (females) avoid dangerous behaviors } \\
\text { behind the wheel }\end{array}$ & & & $.88(.91)$ & \\
\hline $\begin{array}{l}\text { 11I think that males (females) avoid risky behaviors behind the } \\
\text { wheel }\end{array}$ & & & $.87(.88)$ & \\
\hline $\begin{array}{l}7 \text { I think that males (females) refrain from having dangerous } \\
\text { behaviors behind the wheel }\end{array}$ & & & $.87(.77)$ & \\
\hline $\begin{array}{l}\text { 27I think that males (females) avoid engaging in risky situations } \\
\text { behind the wheel }\end{array}$ & & & $.85(.88)$ & \\
\hline 15I think that males (females) avoid to adopt a risky driving & & & $.84(.92)$ & \\
\hline 3 I think that males (females) avoid taking risk while driving & & & $.73(.72)$ & \\
\hline 12I think that males (females) are civic behind the wheel & & & & $.93(.92)$ \\
\hline 20 I think that males (females) show politeness behind the wheel & & & & $.91(.94)$ \\
\hline $\begin{array}{l}\text { 16I think that males (females) show manners to others road } \\
\text { users }\end{array}$ & & & & $.91(.95)$ \\
\hline $\begin{array}{l}\text { 24I think that males (females) show consideration to others road } \\
\text { users }\end{array}$ & & & & $.90(.95)$ \\
\hline 8 I think that males (females) are respectful of others road users & & & & $.87(.87)$ \\
\hline 4 I think that males (females) are courteous drivers & & & & $.75(.79)$ \\
\hline
\end{tabular}


Table 2.

Means (and standard deviations) for each male and female drivers evaluation for each participant's age and sex group

\begin{tabular}{|c|c|c|c|c|c|c|c|c|c|c|c|}
\hline \multirow[t]{2}{*}{ Evaluation score } & \multicolumn{3}{|c|}{ 18-24 years old } & \multicolumn{3}{|c|}{$25-44$ years old } & \multicolumn{3}{|c|}{$25-44$ years old } & \multirow[t]{2}{*}{ Men } & \multirow[t]{2}{*}{ Women } \\
\hline & Men & Women & Total & Men & Women & Total & Men & Women & Total & & \\
\hline Male's driving skills & $34.71(6.56)$ & $35.53(6.96)$ & $34.98(2.89)$ & $33.10(5.16)$ & $35.51(5.90)$ & $35.06(5.35)$ & $34.42(5.63)$ & $35.34(7.62)$ & $34.68(6.78)$ & $34.09(8.87)$ & $35.48(6.78)$ \\
\hline Male's courtesy & $20.21(6.47)$ & $21.29(6.55)$ & $21.24(6.31)$ & $20.50(6.75)$ & $20.08(5.04)$ & $20.14(6.20)$ & $21.77(6.86)$ & $18.84(6.14)$ & $20.22(6.45)$ & $20.71(6.64)$ & $20.39(6.09$ \\
\hline Male's compliance & $19.81(5.82)$ & $20.55(6.95)$ & $20.53(6.47)$ & $22.60(7.44)$ & $22.37(5.52)$ & $21.35(6.62)$ & $25.23(6.99)$ & $19.74(7.50)$ & $22.44(7.43)$ & $22.16(7.00)$ & $20.91(6.72)$ \\
\hline Male's risk avoidance & $20.52(5.73)$ & $21.71(7.47)$ & $21.34(6.77)$ & $23.28(6.39)$ & $22.92(5.81)$ & $22.41(6.72)$ & $25.77(7.18)$ & $22.13(8.09)$ & $23.59(7.26)$ & $22.82(6.65)$ & $22.16(7.15)$ \\
\hline Female's driving skills & $25.25(7.90)$ & $30.16(7.19)$ & $28.90(7.58)$ & $28.20(6.12)$ & $30.29(7.11)$ & $28.24(7.22)$ & $30.35(8.51)$ & $33.87(7.35)$ & $31.97(7.66)$ & $25.57(7.62)$ & $31.01(7.32)$ \\
\hline Female's courtesy & $25.50(7.79)$ & $26.87(6.47)$ & $26.46(6.81)$ & $27.00(6.88)$ & $29.27(7.24)$ & $27.5(7.41)$ & $29.42(6.28)$ & $30.24(5.89)$ & $29.53(6.19)$ & $27.03(7.23)$ & $28.33(6.71)$ \\
\hline Female's compliance & $32.94(6.39)$ & $30.89(7.10)$ & $31.01(7.04)$ & $33.58(7.80)$ & $33.35(6.32)$ & $33.07(6.80)$ & $34.52(6.23)$ & $34.00(6.46)$ & $34.41(6.46)$ & $33.56(6.93)$ & $32.31(6.84)$ \\
\hline Female's risk avoidance & $32.67(8.54)$ & $34.64(7.97)$ & $33.64(8.15$ & $34.53(7.73)$ & $36.59(6.85)$ & $35.13(7.54)$ & $35.35(6.44)$ & $36.84(6.10)$ & $36.28(6.66)$ & $33.99(7.79)$ & $35.70(7.30)$ \\
\hline
\end{tabular}


Figure 1. Endorsement of SSAD index for each participant's age and sex group

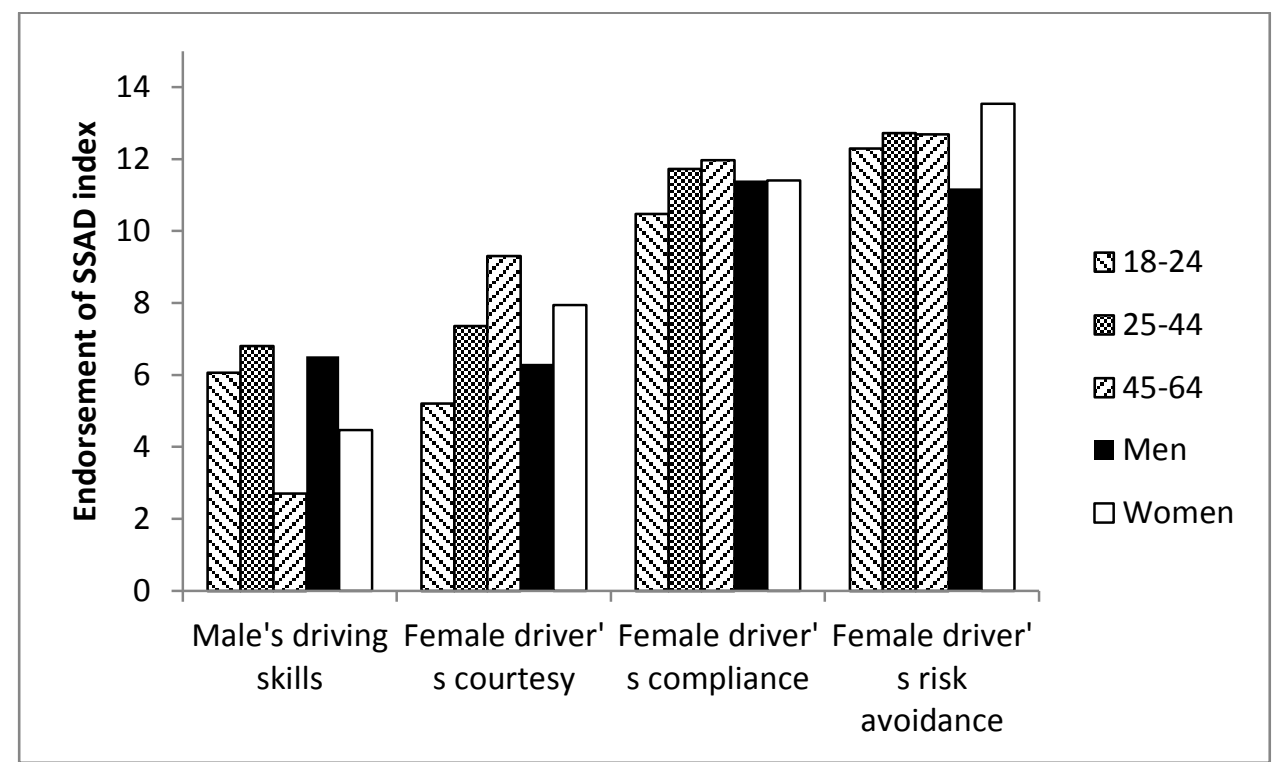

The endorsement indexes corresponded to the difference between participants' evaluation of male and of female drivers:

Male's driving skills index = participants' ratings for male's minus female's driving skills

Female driver's courtesy index = participants' ratings for female's minus male's courtesy behind the wheel

Female driver's compliance index = participants' ratings for female's minus male's compliance with traffic rules

Female driver's risk avoidance index = participants' ratings for female's minus male's risk avoidance 